\title{
HUMAN DIGNITY AND 'IMAGE OF GOD'
}

\author{
Bernd Oberdorfer \\ Systematic Theology \\ University of Augsburg
}

\begin{abstract}
In this article the relation of the theological concept 'image of God' to the socio-juridical concept 'human dignity' is investigated. The popular equation of these concepts is subjected to academic scrutiny, and it is found that the differentiated use of 'image of God' in both the Old and New Testament permits different ways of interpreting this concept. Three historically interrelated and conceptually overlapping ways of interpreting image of God' is suggested and related to the concept of 'human dignity', namely as quality, duty and relation. In conclusion the helpfulness of particularly the relational interpretation is considered.
\end{abstract}

Key Words: Image of God, Human Dignity, Anthropology, Soteriology, Christology

\section{Is 'Image of God' an Appropriate Theological Equivalent to the Concept of Human Dignity?}

The idea of 'human dignity', which is common to every human individual, simply because he or she is human, and upon which are based 'human rights', was only acknowledged in the European mainline churches after the end of World War II (Körtner, 1999). This might seem surprising, because today the churches declare themselves as being advocates of human rights, insisting on its 'Christian roots'. However, for a long time, according to the churches, the idea of human rights epitomized the spirit of secularization, representing an anthropology which focused on the individual without reference to God. This anthropology defined human beings as being autonomous subjects, instead of creatures dependent on God. The idea of human rights seemed to display an individualism that was easily disqualified as egoism, because of its neglect of the commandment of brotherly love, and its apparent disregard for any social commitment.

Certainly, much of this distrust was a result of the historical origins of the idea of human rights, which were strongly linked to the fight for the freedom of religion. Religious freedom was based on the belief that individuals should be given the right to choose his or her religious beliefs without being coerced by the Church or the state. The individual's religious confession should have neither negative nor positive impact on his or her social status (profession, marriage, public posts, etc.). Hence, the churches' influence on the lives of the people greatly decreased. Each church had to learn to accept the right of other churches to publicly articulate their convictions, which were often 'heretical' from their perspective. This began with the Augsburg Religious Peace of 1555, which restricted the right of religious freedom of choice to two churches: Catholics and Lutherans. These two groups, albeit reluctantly, agreed to tolerate each other, but as is well known, were eager to exclude any other group from this right.

Not incidentally, the first declaration of human rights originated in a country, which had given refuge to many of these excluded groups: the United States of America. Presumably, this 'heretical' foundation of human rights hindered the 'importation' of this idea into 'Old 
Europe'. However, the resentment of the churches increased when the French Revolution adopted the human rights idea, together with a strong anti-clericalism. The churches then saw themselves confronted with the challenge of tolerating not only other forms of religion, but also explicit atheism. The freedom of 'believing differently' was supplemented by the right of 'believing in nothing'.

Not only did individual human rights restrict the influence of the churches, but they also restricted the state. What did this development mean for the churches? Crucially, the challenge for them was which anthropology to accept, and according to which religion. The churches came to realize that 'true religion' is not essential to acquire the full dignity of personhood attributed to a human being. Translated into the internal language of Church Dogmatics, the challenge consisted in the following: The idea of a common, unalienable, inviolable human dignity can only be theologically acknowledged, if there is a theological concept which characterizes human beings simply as human beings. This idea of human dignity would also include full human dignity to all persons who are not (or not any longer, or not yet) Christians.

The 'image of God' concept appears to be perfectly suited to supporting this challenge, and there are good reasons to call it the key concept of modern theological anthropology. ${ }^{1}$ Its occurrence in the first narrative of creation in Genesis 1 (Gen 1:26f) seems to qualify it for the most common theological characterization of humankind, compared to which any other descriptions are only second order specifications. This is even underlined by the exegetical observation that the priestly narration adapts the 'image of God' concept from Israel's religious environment. In the Ancient Orient, the term is almost exclusively used for a king, but in the Old Testament (O.T.) it is almost as if it were democratized and that the concept was attributed to every human being. Its exposed position in the beginning of the narratives of God's commitment to the world seems to make it an ideal category for conceiving the specific dignity of human beings - of every human being - before (and thus independent of) any ethnic differentiation, before (and thus independent of) any moral distinction (such as the 'Fall'). Furthermore, there is no evidence of gender discrimination when humankind is declared to be created in the 'image of God' and this is evident in the phrase 'and [He] created them as man and woman'.

But a closer examination of the term in the Bible and in the theological tradition displays a more ambivalent picture and gives rise to many questions. This is already evident when the concept of 'image of God' is presented in the context of Genesis 1 itself. However, the problems increase when we survey the Bible as a whole. Quantitatively, the term 'image of God' does not play a major role in the O.T. Yet, it is conspicuous that human persons are considered to be in the 'image of God' even after the 'Fall' (Gen 9:6). This serves as an argument for the prohibition of murder and for the inviolability of any individual human life. ${ }^{2}$ In the O.T., the terminology does not appear to include the possibility that human beings might lose or damage or decrease their qualification for being in the 'image of God'. However, in the N.T., Jesus Christ is specifically described as being in the 'image of God'. Only 'in Christ', mediated through Christ, in communion with Christ, can other individuals be spoken of as being 'images of God'. But the question arises whether this characteristic can be attributed to any human being - or whether it is exclusively for believers. There are even a few passages where we find a kind of hierarchy

$1 \quad$ Cf., e.g., Ebeling (1982:376): "The concept of image of God (...) is a point of intersection of all crucial dogmatic topics" (my translation). But also cf. the more skeptical remarks in: Pesch (1983).

2 This goes also for Gen 4:15 (Cain), albeit without explicit reference to the concept of 'image of God'. 
of images, for example, only the male is the image of Christ who is the 'image of God'. However, the female is dependent on the male in this regard (cf. 1 Cor 11:3-7).

This Christological concentration of the concept allows two important conclusions. First, 'image of God' does not refer to an 'analytical' quality of a human being in itself, but rather, it is fragile and can be lost or damaged. In fact, it actually is lost or damaged and has to be restored by Christ, who is the 'real' human being, i.e. the human being who corresponds most perfectly to God's will. Second, the term 'in Christ' reveals the concept of the 'image of God' as an eschatological category, and thus it designates a form of existence which combines an arising presence with a future which is still to come - 'already and not yet'. Or, in other words, 'in Christ', a person is already awarded being in the 'image of God', although apart from his or her relation to Christ he or she lacks the crucial characteristics of being in the 'image of God'. To attribute the 'image of God' to someone, thus in some respects does not describe an 'empirical reality', but entails moments of 'more than reality' and even 'against visible reality'.

The second point seems to show certain structural parallels to the concept of 'person' (Oberdorfer, 2000). But unlike 'person', the term 'image of God', as it is used in the New Testament (N.T.), does not qualify the human species as such, and therefore it may be doubted whether it is suitable as an anthropological category anyway. In any case, there has to be a dogmatic explanation of how the 'new' human being 'in Christo' refers to the 'old' human being 'extra Christum' with respect to the 'image of God'. If only the 'new' human being (due to his or her communion with Christ) is imago Dei, then does it mean that the 'old' one is not, or not any longer, or only potentially, or not perfectly, or only in a perverted form?

The crucial relevance of this question becomes evident if we transfer it to the concept of the person. Are there human individuals who are not, or no longer, or only potentially, or not perfectly, or only in a perverted form - persons? As is well known, it was exactly this question which was heavily discussed in the debates on the utilitarian ethics of Peter Singer (1979). Singer declared that it only makes sense to ascribe personhood to an individual if this individual actually possesses certain characteristics and abilities. Consequently, according to him, human individuals who permanently lack these characteristics and abilities need not be addressed as and treated as persons. However, non-human individuals that are endowed with these qualities (e.g. primates and dolphins) have to be considered as persons and should enjoy all the rights of protection that flow from having the dignity of a person. Against this position (with its immense impact on the euthanasia debate) it was argued that the category of the person actually implies certain characteristics and abilities that have to be attributed to the species in general and not necessarily to any individual of the species in particular (Spaeman, 1996). To use a phrase of Dietrich Bonhoeffer: A human (and therefore a person!) is anyone who comes from a human mother.

Thus, if the concept of 'image of God' is supposed to be used within that context, a dilemma arises. If sin damages or even (as the Reformers put it) destroys the imago Dei, then it seems that the concept is not suitable as a fundamental category of anthropology and does not provide a helpful argument in favour of the unalienable personal dignity of any human individual. If the term, conversely, serves as a common characterization of any human being, then it apparently loses its theological complexity.

The fact that very early on, Christian theology started to distinguish elements of the imago Dei, which cannot and can be lost (eikon and homoiosis, or imago and similitudo) shows that from the beginning there was an awareness of the complexity of the concept. In the following section, I will not give a full outline of the historical development of the 
concept, but will rather discuss certain historical positions only in so far as they help to define the systematical problems. My main focus will be on the question: What characterizes the 'image of God'?

\section{Different Interpretations of 'Image of God'}

Considering the history of Christian theology, we can distinguish three basic types of interpretations of the 'image of God' concept, focusing either on quality, or duty, or relation. This does not mean that these three types necessarily mutually exclude each other. However, they are interrelated historically and overlap each other conceptually.

\section{Quality}

Recognizing 'image of God' as a certain quality of the human species has its origins in the biblical narrative of creation, where humans are made in the 'image of God', thus distinguishing humankind from other creatures, vesting it with dominion over them. Not incidentally, therefore, already in the Ancient Church, the theologoumenon 'image of God' was amalgamated with the fundamental anthropological definitions of ancient philosophy. If the human species is defined as zoon logon echon, animal rationale, then the differentia specifica, which distinguishes it from other creatures, is ratio, logos, reason, and even language - owing to the multivalent meaning of the Greek term logos. Inter-textual correlations to the basic claims of biblical anthropology are also evident. Adam names the animals in Genesis 2, implying that he understands what they essentially are; the human mind which is specifically related to the mind of God; the 'Logos' which not only 'was with God' and 'was God', but also 'was made flesh' (John 1). Augustine identified a very special correlation between 'image of God' and the human mind: Looking for 'traces of trinity' (vestigia trinitatis) in creation, he found the threefold structure of the human mind, which operates in a strictly self-referential unity, but is at the same time differentiated by the three functions memoria, intellectus, and voluntas of which every single function respectively represents the whole mind. Thus, being in the 'image of God' means being in the 'image of [the] Trinity' (St Augustine; also see Oberdorfer, 2001).

However, the ability to recognize the 'image of God' in the crucial aspects of human nature has not been limited to the period of the Ancient Church. The insights of modern philosophical and biological anthropology could also be theologically adapted, for example, the 'upright way of walking' or the 'open horizon' (Horizontoffenheit) which enables human beings to always transcend their respective state of being. ${ }^{3}$ Incidentally, physiological dispositions such as the 'upright way of walking' of humans cannot be a reason for humankind's special distinction, because (according Gerhard Ebeling) the penguin would also have to be referred to as being in the 'image of God' (Ebeling, 1982). This upright way of walking refers rather to a physiological prerequisite or indicator of the capacity of human beings to look over the edge, i.e., to transcend the limited spheres of living.

Without doubt, the very strength of this approach lies in its capacity to correlate the theological qualification of humankind with phenomenological descriptions of the human species. Certainly, one of the problems of this method is that it tends to define human nature with respect to what discriminates it from other species. Moreover, the danger of focusing the 'image of God' on a human capacity results in depicting a merely individualistic

3 This method of correlating theological and modern philosophical anthropology is classically represented by Pannenberg $(1964,1983)$. 
and/or rationalist conception of human nature. However, on the other hand this kind of anthropological description could actually stress the crucial relevance of the bodily character of human existence (contrasting, with, for example, the angels). It also could (following old traditions) supplement the formula of animal rationale by the formula of animal sociale in order to emphasize the fundamentally social character of human life. However, as to the latter it is worth mentioning that the formula of animal sociale, taken as such, does not distinguish human kind sharply enough from other species of which many are social too. In this regard, the Greek equivalent of zoon politikon is more precise, because at least in the historical context of its origins, the precise meaning is 'polis-building animal', focusing on the capacity to shape autonomously the common life of free citizens thus including freedom and rationality. ${ }^{4}$ Yet, one of the by products of this increased precision was that it excluded all individuals who were not free and autonomous, namely slaves and women, from full humanity!

However, the theological problem of this type is that it not only correlates, but rather identifies 'image of God' with the most basic qualities of human nature. That the 'image of God' might be 'lost', in a strict sense, cannot be realistically conceived, because this would in a sense abolish all human existence. Confronted with this dilemma, the theological tradition started to differentiate aspects of the 'image of God' which can and which cannot be lost: imago and similitudo. The imago consists in the mentioned basic qualities of human nature and therefore remains in the state of sin. However, the sinner loses the similitudo, because his or her way of living does not correspond to the Creator's will and thus does not represent God. The Reformers declined this model, because they argued that it implied the fatal supposition of a sphere of human reality that was not contaminated by $\sin$ and therefore did not need to be released from it. This contradicted their conviction that humankind was in need of salvation, in a radical and universal sense. Nevertheless, also in Protestant theology the discussion of the dimensions of permanence in the 'image of God' concept could never be suppressed. This is evident in the debate between Karl Barth and Emil Brunner regarding the need for an 'Anknüpfungspunkt' (point of reference) for the gospel in the reality of creation. Brunner focused on language as being the necessary prerequisite to understand the word of God. This is only one particularly prominent example.

Duty

Defining the 'image of God' concept with reference to a specific duty, which humankind is assigned to, is maybe a direct result of reading the text of Genesis 1. Moreover, it also converges with some of the elements of the 'yahwist' narrative in Genesis 2. In Genesis 1, the focus lies with the 'mandate of dominion' to which the 'mandate of propagation' is subordinated. Most interpreters understand the 'mandate of dominion' in the sense of representation. Humankind is God's representative within the sphere 'below heaven', working as a 'housekeeper' of God's 'economy'. Being representative of the Creator within (a part of) creation is humankind's dignity, but also involves responsibility. Humankind has the duty to fulfil, in its particular sphere, God's will concerning this sphere. To use the words of Genesis 2, humankind has been instructed 'to dress and to keep' the earth (Gen. $2: 15)$. By that, humankind is involved in God's work of shaping the world, not simply acting as God's remote-controlled puppet, but rather representing God's freedom too. This presupposes that humankind knows God's will - and is able to both fulfil and not fulfil it,

4 This difference was particularly emphasized by Arendt (1958). 
to correspond to it and to object to it. Not incidentally, in the 'jahwist' paradise narrative, God's command plays a crucial role. Understanding the 'image of God' to be a duty, therefore implies constitutively an element of relation. In either receiving and fulfilling, or objecting to God's command, humankind stands opposite to God.

It may be argued that human beings can only be considered 'images of God' in the world if and in so far as they correspond to God's will in their behaviour. As soon as they stop fulfilling their duty, they can no longer be called 'images of God'. The only remaining option would be to confront them with the command which they failed to fulfil, and to demand that they return to a life that corresponds to God's will and thus to take responsibility for their role in creation. Interestingly enough, the Priesterschrift regards humankind to be the 'image of God' without qualification, even after the Fall (i.e. under the condition of human evil), and this emphasises the physical inviolability of every human individual. It appears that being an 'image of God' does not depend on the actual fulfilment of God's mandate. Human beings are 'images of God' even when they contradict God's will. Therefore, if we are not willing to eliminate from the concept of 'image of God' any reference to the 'mandate of dominion' - it is necessary to view it as being 'against reality' (or instead - 'lacking reality'). The reason for being an 'image of God' is not the actual fulfilment of God's command, but the fact that humankind is honoured with that mandate. In this respect, the 'image of God' cannot actually be lost.

Interestingly, the approach from a human quality perspective might lead to similar reflections if we focus on freedom as a human 'quality'. If the 'mandate of dominion' involves a free participation of humankind in God's 'governance of the world' and if freedom is therefore commensurate with the concept of the 'image of God', then this includes the idea that this freedom still exists despite the renunciation of God's command. However, this evokes a paradox which is hard to accept: the paradox that even resistance against God must be interpreted as an expression of being in the 'image of God'. The theological tradition tried to solve this problem by distinguishing formal and material aspects of freedom: formally, freedom as part of the nature of humankind (which is 'image of God') is maintained even in the case that materially it is activated in opposition to its original destination. The Reformers objected to this distinction, because assuming formal continuity seemed to imply the claim of an incorrupt or even an indestructible substance or essence of humankind on which sin has no impact. They did not doubt that from God's 'top-down' perspective humankind remained indestructibly in the 'image of God'. But at the level of the reality of human existence they denied any continuity; from a 'bottom-up' perspective the 'image of God' must be regarded as totally lost. Since Adam's fall, like a famous Reformation hymn says, human nature has been 'totally corrupted' ('ganz verderbt'). Thus, the 'image of God' consists neither in the attribution of a quality nor in the honour of a mandate, but rather alone in God the Creator's loyalty to his own will. In other words, humankind is in the 'image of God' only because and in so far as God, without reference to any achievements, has elected and destined it to be so. However, with this idea we have already passed the line to a relational understanding of 'image of God'.

\section{Relation}

Relational understanding does not mean that the inter-human community represents God within creation, whether in the problematic form of the matrimonial community ('and created them male and female'), or in the wider sense of a love-orientated community. This 
would result in nothing more than a variant of the other types, because 'image of God' would be defined in relation to a human quality or activity. ${ }^{5}$ Relationality rather constitutes a different type of 'image of God'. It regards human beings as 'images of God' because of their relation to God, because of their existence in the face of God, and because of their turning to God. By faithfully answering to God and thus honouring God, a human being proves to be an authentic witness of God within the world. Thus being 'image of God' does not become a reality by activating a human quality or by fulfilling a duty, but rather by faith. Certainly, faith also includes obedience to the will of God and implies consequences for human actions that shape the world; but its focus actually lies in the faithful turning to God, and by that it represents God within the world.

It is fairly clear that this understanding of 'image of God' is based on the doctrine of justification. Two conclusions are derived from this doctrine and these are difficult to coordinate. On the one hand, being 'image of God' is strictly a gift, independent of any qualities or the fulfilling of duties. Therefore, it would be a categorical mistake to claim that it could be 'lost' by human misbehaviour. However, it is evident that a human being, if he or she does not believe in God, honour God, and authentically witness to God, is not actually an 'image of God' in the world. The conclusion seems inevitable that the non-believer or the sinner 6 is not an 'image of God'. To speak of the 'loss' of being in the 'image of God' depends on whether the Adamite state (status integritatis) is regarded as a 'historical' state from which humankind 'fell' or whether the biblical narratives of Creation are only interpreted as a mythical expression of the creational 'destination of humankind'.

Either way it is clear that if the 'image of God' concept is understood with reference to the doctrine of justification, the concept cannot simply operate as a quality of the human species. From God's perspective, 'image of God' is a gift of salvation for the 'elect', and this election is based on itself, and does not depend on any capacities or achievements which can be recognized by the individual or by others. Therefore, from humankind's perspective it cannot be objectified as if it were a proven fact.

As far as I can see, this soteriological and relational type of understanding of the 'image of God' is widely accepted in contemporary theology. There are good reasons for this, but it seems to make impossible the anthropological use of the concept, because it appears only to imply universality in a negative sense. There is no human being whose actual way of living would allow him or her to be identified as an 'image of God'. On the positive side, we only seem to have the particularistic understanding of election by God. In the concluding section, I will deal with this objection, asking whether the Christological focus does not also entail universalistic implications - in a positive sense.

\section{Christological Focus and Eschatological Universality}

First of all, it has to be emphasized that soteriology always has references to the Creation story. Therefore, the theological tradition had good reasons, when it started out from

5 This social analogy needs not necessarily be explicated in a Trinitarian way (like Barth did). It is unclear yet how the idea of community is related to the 'mandate of dominion'.

6 In some respects, the term 'non-believer' seems to be more precise than the term 'sinner', because the latter might suggest a moralistic misunderstanding. However, sin is basically non-correspondence to the will of God, which can - but need not - articulate itself in moral misbehaviour. In other respects, conversely, the term 'sinner' seems to denote the universality of the phenomenon more clearly than the term 'non-believer' which appears to designate only one of two subsets. However, the believer eliminates this separation by acknowledging the fragility of his or her own faith: 'Lord, I believe, help my unbelief' (Mark 9:24). 
soteriology, to regain anthropological universality. Both of the decisive arguments for this are Christological: First, Christ's work of salvation is not restricted to a limited group, but rather aims at all people. Second, Christ as a 'real human being' (vere homo), is representative of all human beings, by fulfilling the creational 'destination of the human species' to be an 'image of God' on behalf of humanity. When the N.T. radically focuses the concept of 'image of God' on Christ, this actually has a strong leaning towards creation-based universality. 'Overcoming the world' - as the Gospel puts it (John 16:33) - does not eliminate the fact that we are creatures, but rather fulfils the destination that God gave to his creatures. Christ corresponds perfectly to God's will, which Adam had contradicted. Therefore, the N.T. use of 'image of God' does not detract from its use in the O.T., but rather is based on it, comments on it, and gives a soteriological and eschatological emphasis to it.

However, if being in the 'image of God' is mediated through Christ and becomes real by the gift of participation in Christ, communion with Christ, and faith in Christ, the critique of the particularity of the Christian concept of 'image of God' seems to be strengthened rather than invalidated, because as is evident, not everybody actually believes.

Yet, it helps to consider precisely the function of the term 'image of God' in anthropological and ethical contexts. Actually, it is supposed to attribute to any person a dignity which is not dependent on capabilities or achievements. Therefore, it cannot be limited or eliminated in the case of a lack of ability. It is a dignity which cannot be withdrawn and which even an individual cannot withdraw from him or herself. How can it be stated, in this sense, that all human beings are 'images of God'?

Essentially, there are three arguments to be brought forward. First, the universality of Christ's work of salvation does not exclude any individuals a priori. No one can claim that he or she definitely will not participate in a communion with Christ or that he or she has definitely lost it. Conversely, this universality of Christ's work of salvation commits Christians to treat non-Christians as people to whom Christ's work is valid as well, although they do not (yet) know or acknowledge it. Second, faith includes a knowledge of its own persistent fragility and of the continuous need of redemption; this prevents any fixed discrimination of persons 'in' and 'out' of salvation. Third, the eschatological character of salvation implies a dynamic culture of expectation, which recognizes the present status quo as transformable and as it were imagines amidst the present state its future fulfilment.

Thus, the fact that the 'image of God' concept developed via Christology enables one to give it a more complex and more differentiated form, which removes it from the idea of a substantial state of being. Moreover, the alternative of either counter-real attribution or real possession of being in the 'image of God' proves to be inadequate. Actually, 'image of God' is not an empirical quality, but nevertheless it realizes the creational destination of humankind. And as certain as the vocation to be 'image of God' is independent of any personal capabilities and achievements, so it is certain that the promulgation of God's unqualified attribution of being 'image of God' in the communication of faith motivates an inner-worldly evolutionary dynamic through which individuals help each other to 'be made conformable' to Christ (cf. Phil 3:10). Thus the unqualified attribution of being 'image of God' does not simply constitute a trans-empirical reality that has no other empirical impact than the passive 'God loves you as you are'. It rather motivates an individual as well as a social way of living that mirrors the ascribed dignity. Whenever this does not succeed, the dignity of being an 'image of God' may be obscured, contorted or caricatured - but it cannot be lost or destroyed in anyway. 


\section{BIBLIOGRAPHY}

Arendt, H 1958. The Human Condition. Chicago: University of Chicago Press.

Ebeling, G 1982. Dogmatik des christlichen Glaubens I. Tübingen: Mohr Siebeck.

Körtner, UHJ 1999. Evangelische Sozialethik. Göttingen: Vandenhoeck \& Ruprecht.

Oberdorfer, B 2000. Umrisse der Persönlichkeit. Personalität beim jungen Schleiermacher - ein Beitrag zur gegenwärtigen ethischen Diskussion. Evangelische Theologie, 60, 9-24.

Oberdorfer, B 2001. Filioque: Geschichte und theologie eines ökumenischen Problems. Göttingen: Vandenhoeck \& Ruprecht.

Pannenberg, W 1964. Was ist der Mensch? Göttingen: Vandenhoeck \& Ruprecht.

Pannenberg, W 1983. Anthropologie in theologischer Perspektive. Göttingen: Vandenhoeck \& Ruprecht.

Pesch, OH 1983. Frei sein aus Gnade. Theologische Anthropologie. Freiburg: Herder Verlag.

Singer, P 1979. Practical Ethics. Cambridge: Cambridge University Press.

Spaemann, R 1996. Personen. Versuche über den Unterschied zwischen 'etwas' und 'jemand'. München: CH Beck.

St. Augustine c.416/2002. De trinitate, lib. IX-X. Gareth B Matthews, (ed.). Augustine: On the Trinity [Books 8-15], Cambridge Texts in the History of Philosophy. Cambridge: Cambridge University Press. 